\title{
Role of endothelial miR-24 in COVID-19 cerebrovascular events
}

\author{
Jessica Gambardella 1,2, Antonietta Coppola ${ }^{3}$, Raffaele Izzo², Giuseppe Fiorentino ${ }^{3}$, Bruno Trimarco ${ }^{2}$ and \\ Gaetano Santulli ${ }^{1,2^{*}}$ (D)
}

Levels of microRNAs (miRNAs) within extracellular vesicles (EVs) have been shown to be useful diagnostic and prognostic biomarkers in a number of disease states [13]. However, EVs miRNAs have never been investigated in COVID-19.

We recently demonstrated that miR-24 is expressed in human brain endothelial cells (ECs) and targets Neuropilin-1 [4], a co-factor needed for SARS-CoV-2 internalization that has been linked to cerebrovascular (CBV) manifestations of COVID-19 [5]. Henceforth, we hypothesized an association between plasma levels of endothelial EV miR-24 and the onset of CBV events in patients hospitalized for COVID-19. CBV events were defined by the presence of ischemic or hemorrhagic stroke (confirmed by imaging), migraine, or transient ischemic attack (no findings at imaging evaluation).

We obtained plasma from 369 patients hospitalized for COVID-19, consecutively enrolled from November 2020 to April 2021 at the "Ospedali dei Colli". We excluded 48 patients with a history of CBV disease, cancer, atrial fibrillation, deep vein thrombosis, or unavailability of admission blood samples; thus, the study was conducted in 321 subjects. As a control age- and sexmatched COVID-19 negative population, we obtained plasma from 57 healthy donors and 37 patients with CBV disorders. A SARS-CoV-2 test (RT-qPCR) was performed in all subjects to confirm or rule out the COVID-19

\footnotetext{
*Correspondence: gaetano.santulli@einsteinmed.org

${ }^{1}$ Departments of Medicine (Cardiology) and Molecular Pharmacology, Wilf Family Cardiovascular Research Institute, Einstein Institute for Aging Research, Einstein-Sinai Diabetes Research Center, Albert Einstein College of Medicine, New York, NY, USA

Full list of author information is available at the end of the article
}

diagnosis. EC-EVs were extracted from the plasma collected from these patients via serial centrifugation and $\mathrm{CD} 1^{+}$magnetic isolation [1], and EC-EVs miR-24 levels were quantified as described $[1,4,6]$.

Clinical parameters of our population are reported in Table 1. CBV events were diagnosed in 58 COVID-19 patients. No significant differences in comorbidities and in therapeutic management were observed. We found that EC-EV miR-24 levels were significantly reduced in patients with $v s$ without CBV disorders among COVID19 patients, but not when examining subjects without COVID-19 (Table 1). These results were confirmed when subdividing our population according to the presence of ischemic or hemorrhagic findings at imaging evaluation (Fig. 1). Strikingly, using a stepwise multiple regression analysis, adjusting for age, hypertension, dyslipidemia, diabetes, and D-dimer, the association between EC-EV miR-24 and CBV disease in COVID-19 patients was confirmed [Wald: 17.723 ; $\operatorname{Exp}(B): 0.955$, C.I. $95 \%$ : 0.935$0.976, P<0.001]$.

To our knowledge, this is the first study showing an association between EC-EV non-coding RNA and clinical outcome in COVID-19 patients.

The main limitation of the present study is the relatively small size of our population; moreover, our findings, which are limited to Caucasian individuals, refer to subjects that have been hospitalized for COVID-19 and therefore cannot be generalized to patients with a mild disease.

We identified a significant association linking EC-EV miR-24 and CBV disorders, which could be valuable to understand the mechanisms underlying the pathophysiology of CBV complications in COVID-19. Indeed, low

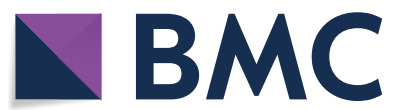

(c) The Author(s) 2021. Open Access This article is licensed under a Creative Commons Attribution 4.0 International License, which permits use, sharing, adaptation, distribution and reproduction in any medium or format, as long as you give appropriate credit to the original author(s) and the source, provide a link to the Creative Commons licence, and indicate if changes were made. The images or other third party material in this article are included in the article's Creative Commons licence, unless indicated otherwise in a credit line to the material. If material is not included in the article's Creative Commons licence and your intended use is not permitted by statutory regulation or exceeds the permitted use, you will need to obtain permission directly from the copyright holder. To view a copy of this licence, visit http://creativecommons.org/licenses/by/4.0/. The Creative Commons Public Domain Dedication waiver (http://creativeco mmons.org/publicdomain/zero/1.0/) applies to the data made available in this article, unless otherwise stated in a credit line to the data. 
Table 1 Main characteristics of our population

\begin{tabular}{|c|c|c|c|c|c|c|}
\hline & \multicolumn{3}{|c|}{ COVID-19 negative } & \multicolumn{3}{|c|}{ COVID-19 positive } \\
\hline & $\begin{array}{l}\text { NO CBV } \\
(57)\end{array}$ & $\begin{array}{l}\text { CBV } \\
(37)\end{array}$ & $P$ & $\begin{array}{l}\text { NO CBV } \\
(263)\end{array}$ & $\begin{array}{l}\text { CBV } \\
(58)\end{array}$ & $P$ \\
\hline Age (years) & $59.4 \pm 14.78$ & $65.37 \pm 12.75^{*}$ & 0.04 & $61.5 \pm 14.2$ & $63.6 \pm 14.6$ & 0.292 \\
\hline Sex (male, \%) & 50.9 & 59.5 & 0.42 & 54.7 & 55.1 & 0.954 \\
\hline $\mathrm{BMI}\left(\mathrm{kg} / \mathrm{m}^{2}\right)$ & $25.62 \pm 3.83$ & $25.44 \pm 2.9$ & 0.8 & $24.93 \pm 3.59$ & $25.01 \pm 2.9$ & 0.865 \\
\hline $\mathrm{SBP}(\mathrm{mmHg})$ & $133.88 \pm 16.1$ & $143.08 \pm 19.3^{*}$ & 0.014 & $137.76 \pm 19.5$ & $142.2 \pm 19.3$ & 0.114 \\
\hline $\mathrm{DBP}(\mathrm{mmHg})$ & $79.93 \pm 9.5$ & $84.38 \pm 8.8^{*}$ & 0.025 & $84.46 \pm 9.47$ & $86.3 \pm 14.9$ & 0.239 \\
\hline Hypertension (\%) & 26.3 & $51.3^{*}$ & 0.013 & 39.9 & 44.8 & 0.493 \\
\hline Glycemia (mg/dl) & $104.9 \pm 22.2$ & $112.2 \pm 27.8$ & 0.163 & $109.39 \pm 28.2$ & $112.48 \pm 42.7$ & 0.497 \\
\hline Diabetes (\%) & 7.0 & $21.6^{*}$ & 0.039 & 12.5 & 17.2 & 0.344 \\
\hline Dyslipidemia (\%) & 24.5 & 43.2 & 0.059 & 30.8 & 34.4 & 0.586 \\
\hline Smoking (current/past, \%) & $14 / 22.8$ & $21.6 / 37.8^{*}$ & 0.032 & 18.2/26.6 & $12.1 / 34.4^{\#}$ & 0.081 \\
\hline D-dimer $(\mu \mathrm{g} / \mathrm{ml})$ & $2.35 \pm 1.73$ & $3.52 \pm 0.95^{*}$ & 0.001 & $2.80 \pm 1.68$ & $3.18 \pm 1.83$ & 0.120 \\
\hline IL-6 (pg/ml) & $1.7 \pm 1.1$ & $4.0 \pm 2.8^{*}$ & 0.002 & $7.5 \pm 4.0^{\#}$ & $8.4 \pm 5.5^{\#}$ & 0.121 \\
\hline TNFa (pg/ml) & $4.5 \pm 2.3$ & $6.0 \pm 4.7^{*}$ & 0.035 & $6.5 \pm 4.2$ & $5.8 \pm 4.7$ & 0.271 \\
\hline hs-CRP ( $\mu \mathrm{g} / \mathrm{ml})$ & $2.15 \pm 1.1$ & $2.6 \pm 1.16$ & 0.07 & $3.6 \pm 3.2^{\#}$ & $4.2 \pm 2.9^{\#}$ & 0.144 \\
\hline EC-EV miR-24 (copies/10 nl) & $30.5 \pm 14.6$ & $29.85 \pm 15.5$ & 0.827 & $26.64 \pm 20.9^{\#}$ & $15.41 \pm 14.7^{*, \#}$ & 0.001 \\
\hline
\end{tabular}

All $P$ values in the table are reported in italic

Data on quantitative parameters are expressed as mean \pm standard deviation; data on qualitative characteristics are expressed as percentage values or absolute numbers. BMI: Body mass index; CBV: cerebrovascular (events); DBP: diastolic blood pressure; EC-EV miR-24: level of miR-24 shuttled by endothelial (CD31+) extracellular vesicles; hs-CRP: high-sensitivity C-reactive protein; IL-6: interleukin-6; SBP: systolic blood pressure; and TNFa: tumor necrosis factor a. Following verification of normality (Shapiro-Wilk's test) and equal variance (Bartlett's test), continuous variables were compared using ANOVA followed by Tukey-Kramer test for independent samples, whereas variables not normally distributed were compared via the Kruskal-Wallis test; categorical data were compared using the $X^{2}$ test; ${ }^{*} P<0.05$ versus NO CBV; ${ }^{\#} P<0.05$ versus COVID-19 negative

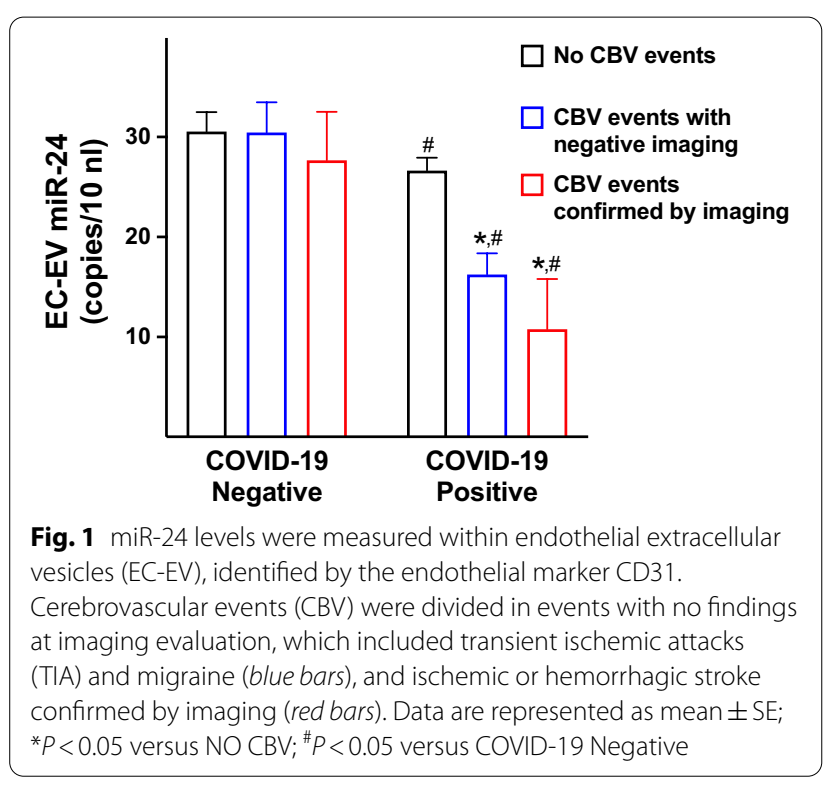

levels of EC-EV miR-24 suggest an increased expression of Neuropilin-1 in ECs [4]. Further analyses in larger groups are warranted to ratify our results, confirm their prognostic value, and investigate the role of miR-24 in other COVID-19-related neurologic events.

\section{Acknowledgements}

We thank Drs. Stanislovas S. Jankauskas, Daniela Sorriento, Xujun Wang, and Anna Annunziata for helpful discussion.

\section{Authors' contributions}

JG, AC, Rl, and GF obtained data. JG, BT, and GS analyzed and discussed the data. JG and GS wrote the manuscript. All authors read and approved the final manuscript.

\section{Funding}

The Santulli Lab is supported in part by the National Institutes of Health $(\mathrm{NIH}$ : R01-DK123259, R01-DK033823, R01-HL146691, R01-HL159062, R56-AG066431, and T32-HL144456 to G.S.), by the Irma T. Hirschl and Monique Weill-Caulier Trusts (to G.S.), and by the AHA (20POST35211151) to J.G.

\section{Availability of data and materials}

The datasets used and/or analyzed during the current study are available from the corresponding author on reasonable request.

\section{Declarations}

\section{Ethics approval and consent to participate}

The study was performed in accordance with the ethical standards laid down in the 1964 Declaration of Helsinki and its later amendments and was approved by the local Institutional Review Board, and informed consent was obtained.

\section{Consent for publication}

Not applicable. 


\section{Competing interests}

The authors declare that they have no competing interests.

\section{Author details}

${ }^{1}$ Departments of Medicine (Cardiology) and Molecular Pharmacology, Wilf Family Cardiovascular Research Institute, Einstein Institute for Aging Research, Einstein-Sinai Diabetes Research Center, Albert Einstein College of Medicine, New York, NY, USA. ${ }^{2}$ International Translational Research and Medical Education (ITME) Consortium, Department of Advanced Biomedical Sciences, "Federico II" University, Naples, Italy. ${ }^{3}$ COVID-19 Division, Azienda Ospedaliera di Rilevo Nazionale (AORN) "Ospedali dei Colli", Naples, Italy.

Received: 9 May 2021 Accepted: 13 August 2021

Published online: 25 August 2021

\section{References}

1. Prattichizzo F, De Nigris V, Sabbatinelli J, Giuliani A, Castano C, Parrizas M, Crespo I, Grimaldi A, Baranzini N, Spiga R, et al. CD31(+) extracellular vesicles from patients with type 2 diabetes shuttle a miRNA signature associated with cardiovascular complications. Diabetes. 2021;70(1):240-54.
2. Mori MA, Ludwig RG, Garcia-Martin R, Brandao BB, Kahn CR. Extracellular miRNAs: from biomarkers to mediators of physiology and disease. Cell Metab. 2019;30(4):656-73.

3. Santulli G. microRNA: Medical Evidence - From Molecular Biology to Clinical Practice. Hardcover Book (Springer International Publishing, Switzerland), 2015; ISBN: 978-3-319-22670-5. https://doi.org/10.1007/ 978-3-319-22671-2.

4. Mone P, Gambardella J, Wang X, Jankauskas SS, Matarese A, Santulli G. miR-24 Targets the Transmembrane Glycoprotein Neuropilin-1 in Human Brain Microvascular Endothelial Cells. Noncoding RNA. 2021;7(1):9.

5. Mayi BS, Leibowitz JA, Woods AT, Ammon KA, Liu AE, Raja A. The role of Neuropilin-1 in COVID-19. PLoS Pathog. 2021;17(1):e1009153.

6. Santulli G, Wronska A, Uryu K, Diacovo TG, Gao M, Marx SO, Kitajewski J, Chilton JM, Akat KM, Tuschl T, et al. A selective microRNA-based strategy inhibits restenosis while preserving endothelial function. J Clin Invest. 2014;124(9):4102-14.

\section{Publisher's Note}

Springer Nature remains neutral with regard to jurisdictional claims in published maps and institutional affiliations.
Ready to submit your research? Choose BMC and benefit from:

- fast, convenient online submission

- thorough peer review by experienced researchers in your field

- rapid publication on acceptance

- support for research data, including large and complex data types

- gold Open Access which fosters wider collaboration and increased citations

- maximum visibility for your research: over $100 \mathrm{M}$ website views per year

At BMC, research is always in progress.

Learn more biomedcentral.com/submissions 